\title{
Alleviation of Adverse Effects of Salt Stress in Wheat Cultivars by Foliar Treatment with Antioxidant 2-Changes in Some Biochemical Aspects, Lipid Peroxidation, Antioxidant Enzymes and Amino Acid Contents
}

\author{
Ebtihal M. Abd Elhamid1, Mervat Sh. Sadak ${ }^{1}$, Medhat M. Tawfik ${ }^{2}$ \\ ${ }^{1}$ Botany Department, Division of Agricultural and Biology, National Research Centre, Cairo, Egypt \\ ${ }^{2}$ Field Crops Research Department, Division of Agricultural and Biology, National Research Centre, Cairo, Egypt \\ Email: "mervat sh24@yahoo.com
}

Received 29 September 2014; revised 25 October 2014; accepted 10 November 2014

Academic Editor: Zacharia J. Malley, Agricultural Research Institute, Uyole, Tanzania

Copyright (C) 2014 by authors and Scientific Research Publishing Inc.

This work is licensed under the Creative Commons Attribution International License (CC BY).

http://creativecommons.org/licenses/by/4.0/

(c) (i) Open Access

\section{Abstract}

Ascobin (compound composed of ascorbic acid and citric acid) is considered one of exogenous protectants which may alleviate the harmful effects of salinity stress. Pot experiments were performed at the screen greenhouse of National Research Centre, Cairo, Egypt to study the effect of foliar treatment of two cultivars of wheat plant with different concentrations of ascobin $(0,200,400$ and $600 \mathrm{mg} / \mathrm{l}$ ) on some biochemical parameters, antioxidant enzymes, element contents and amino acid constituents of two cultivars of wheat plant grown under different salinity levels $(0.0$, 3000 and $6000 \mathrm{mg} / \mathrm{l}$ ) in 2011/2012 and 2012/2013. Salinity with different concentrations levels increased phenolic compounds contents of the two wheat cultivars. The activities of antioxidant enzymes (SOD, CAT, POD, PPO, AXP and GR) dramatically increased due to salinity stress. Amino acid content was increased in cultivar Sids 1 , while the content was decreased in cultivar Giza 168 in all salinity treatments. Increments in the above mentioned parameters compared to the untreated plants at normal and stressed conditions. The magnitude of increments was much more pronounced in response to $600 \mathrm{mg} / \mathrm{l}$ of ascobin. It could be concluded that, foliar treatment of wheat cultivars with ascobin could partially alleviate the harmful effect of salinity especially at the lower levels of salinity of the two cultivars of wheat at most of the studied parameters.

${ }^{*}$ Corresponding author. 


\section{Keywords}

\section{Amino Acid, Antioxidant Enzymes, Ascobin, Phenolic Contents, Salinity Wheat}

\section{Introduction}

Wheat (Triticum aestivum L.) is one of the important growing cereal crops in Egypt. Although wheat production per unit area in Egypt has significantly increased during the past years, wheat production supplies about $40 \%$ of its annual domestic demand and it is still essential to increase wheat productivity. Extending wheat growing outside the Nile Valley where most of its area suffers from salinity or depends on water sources having relatively higher level of salinity. Therefore, there is a need to find means for enhancing the ability of wheat to tolerate salinity and consequently increase its productivity under salinity stress conditions, which limit growth and productivity of most agricultural crops [1]. Salinity imposes both ionic and osmotic stresses on plants. Salt tolerance in plants is a complex trait, which varies widely among closely related species and even of different varieties of the same species. Differences between closely related plants are particularly interesting to identify a small number of factors responsible for salt tolerance [2]. Salinity stress has been studied in relation to regulatory mechanisms of osmotic and ionic homeostasis. Tolerant genotypes respond to salinity stress with complex changes in their physiological and molecular status. During the course of salinity stress, active solute accumulation of osmotic solutes such as soluble carbohydrates, proteins and free amino acids is claimed to be an effective stress tolerance mechanism. The adaptability of plant species to high salt concentrations in soil by lowering tissue osmotic potential was accompanied by accumulation of these osmotic solutes [3]. Due to salinity, growth reduction is also credited to ion toxicity and nutrient imbalance, which not only causes high sodium $\left(\mathrm{Na}^{+}\right)$and chloride $\left(\mathrm{Cl}^{-}\right)$accumulation in plants, but also destructively affects the uptake of essential nutrient elements such as potassium $\left(\mathrm{K}^{+}\right)$, calcium $\left(\mathrm{Ca}^{2+}\right)$ and magnesium $\left(\mathrm{Mg}^{2+}\right)$ in contrast with $\mathrm{Na}^{+}$and $\mathrm{Cl}^{-}$. Cations such as $\mathrm{K}^{+}$and $\mathrm{Na}^{+}$are recognized to be the main inorganic elements, which make available the needed osmotic potential for water uptake by plant cells. The ratio of $\mathrm{K}^{+}$and $\mathrm{Na}^{+}$in the cytosol is necessary for usual cellular functions of plants [4]. In addition, several factors associated with salinity stress can lead to an increase in reactive oxygen species (ROS). By scavenging free radicals, an active antioxidative defense system comprising enzymatic and non-enzymatic antioxidants reduces the level of oxidative stress in plant cells [5]. At the cellular level, salt inducing oxidative damage can be determined by malondialdehyde, a lipid peroxidation product, which is accumulated in plants under saline stress [6].

Recently, a great attention has been focused on the possibility of using natural and safety substances in order to improve plant growth, flowering and fruit setting. In this concern, antioxidants have synergistic effects on growth, yield and yield quality of many plant species. These compounds have beneficial effects on catching the free radicals or the active oxygen (singlet oxygen, superoxide anion, hydrogen peroxide, hydroxyl radicals and ozone) produced during photosynthesis and respiration processes [7]. One of the most familiar antioxidants is ascorbic acid which is synthesized in higher plants and affects plant growth and development [8]. The ability of ascorbate to lose or donate electrons to produce monodehydroascorbate (MDHA) is the basis of its biologically useful antioxidant capacity [9]. Thus, high endogenous AsA in plants is necessary to counteract oxidative stress in addition in regulating other processes of plant metabolism. Endogenous AsA can be increased by exogenous application of AsA through the rooting medium [10], as a foliar spray or as seed priming. Citric acid is among the inter mediate organic acids in Krebs cycle which produces cellular energy by oxidative phosphorylation [11].

Therefore, the present investigation aims to study the effect of ascobin (mixture of ascorbic acid + citric acid at 60:40) on some biochemical compounds and antioxidant enzyme activities, lipid peroxidation, macro element and amino acid contents of two cultivars (Sids 1 and Giza 128) of wheat plant growing under salinity stress.

\section{Materials and Methods}

A pot experiment was conducted in the greenhouse of the National Research Centre, Dokki, Cairo, Egypt in the winter seasons of 2011/2012 and 2012/2013 to study the effect of salinity and ascobin (mixture of ascorbic acid + citric acid in the ratio of 2:1) on some biochemical and antioxidant activities, lipid peroxidation and amino 
acid constituents of two cultivars of wheat plant growing under salinity stress. The treatments were as follows:

a) Salinity: Irrigation by salt water with concentrations tap water (TW) as a control (300 mg/l) 3000, 6000 $\mathrm{mg} / \mathrm{l}$ and their EC concentrations are equal 0.03, 3.2 and $6.1 \mathrm{dsm}^{-}$respectively. The salt type used in irrigation was mainly the chloride mixture suggested by [12]. The salt components of salt mixture are shown in Table 1.

b) Ascobin (ascorbic acid and citric acid 2:1): Spraying of ascobin in the rate of 200, 400 and $600 \mathrm{mg} / \mathrm{l}$ twice at 30 and 45 days from sowing. Experimental pot contained $30 \mathrm{Kg}$ of air dried clay loam soil and sandy soil in the ratio of 2:1. Grains of wheat (Triticum aestavum L.) C.V. Sids 1 and Giza 168 (obtained from Agricultural Research Centre Giza, Egypt) sown in the 1st December, 2011 and 2012. Calcium super phosphate $\left(15.5 \% \mathrm{P}_{2} \mathrm{O}_{5}\right)$ and potassium sulfate $\left(48 \% \mathrm{~K}_{2} \mathrm{O}\right)$ in the rate of 3.0 and $1.50 \mathrm{~g} /$ pot were added, respectively, before planting. Ammonium sulfate $(20.5 \% \mathrm{~N})$ in the rate of $6.86 \mathrm{~g} /$ pot was added in two equal doses, the first one was add after two weeks from sowing and the 2nd two weeks later. Thinning was done after 15 days so that 5 uniform seedlings/pot were left for other tested parameters. Irrigation with different salt water solution in different concentrations (two irrigations by salt water and the next was by freshwater alternatively). Every treatment consisted of 5 replicates distributed in a completely randomized design system.

Plant samples were taken at vegetative stage (75 days after sowing) for determination of some biochemical compound such as phenolic contents, lipid peroxidation, some oxidative enzyme activities, amino acid and macro elements in the two cultivars shoots of wheat.

Biochemical analysis: The method used for extraction and determination of total phenolic compounds were extracted as described by [13] and determined according to method described by [14]. The levels of lipid peroxidation were measured by determining the levels of malondialdhyde (MDA). Malondialdhyde is a product of lipid peroxidation and was assayed by thiobarbituric acid reactive sustrates (TBARS) contents using the method of [15]. Amino acid contents of wheat shoots protein were determined by using HPLC (Eppdrof, Germany). Macroelement contents of N, P, K, P, Ca, Mg and Na were determined according to the method described by [16].

Enzyme determination: The method used for extracting the enzyme was that of [17]. Super oxide dismutase (SOD, EC 1.12.1.1) activity measured according to the method of [18]. Catalase (CAT, EC 1.11.1.6) activity assayed according to the method of [19]. Peroxidase (POD. EC 1.11.1.7) activity assayed according to the method described by [20]. Polyphenol oxidase (PPO, EC 1.10.3.1) activity assayed using the method of [21]. The activity of ascorbate peroxidase (APX, EC 1.11. 1. 11) was assayed according to [22]. The activity of glutathione reductase (GR, EC 1. 6. 4. 2) was measured according to [23]. All the enzyme activities were calculated and expressed as unit $\min ^{-1} \cdot \mathrm{g}^{-1}$ fresh weight.

The obtained results were subjected to the statistical analysis by M-STAT-C statistical analysis program [24]. Since the trend was similar in both seasons, Bartlett's test and the combined analysis of the two growing seasons were applied. Means were compared using least significant difference test at 5\% level.

\section{Results and Discussion}

Total phenolic content: Total phenolic content of shoot of the two used cultivars exposed to different concentrations of salinity stress is shown in Figure 1. The amount of total phenolic content increased significantly and gradually with increasing salinity levels. The highest amount of total phenolic was observed in shoot exposed to $6000 \mathrm{mg} / \mathrm{l}$ salinity level of the two cultivars. Data also show that cultivar Sids 1 gave higher total phenolic content than cultivar Giza 168 in response to salinity stress. The results also revealed that, foliar treatment with

Table 1. (a) The component of salt mixture used for salinization expressed as \% of total salt content; (b) The component of specific anions and cations in the mixture expressed as percentage of total milliequivalents.

(a)

\begin{tabular}{|c|c|c|c|c|c|c|}
\hline $\mathrm{MgSO}_{4}$ & & $\mathrm{CaSO}_{4}$ & & $\mathrm{NaCl}$ & $\mathrm{MgCl}_{2}$ & $\mathrm{CaCO}_{3}$ \\
\hline \multirow[t]{2}{*}{10} & & 1 & & 78 & 2 & 9 \\
\hline & & & & (b) & & \\
\hline $\mathrm{Na}^{+}$ & $\mathrm{Mg}^{2+}$ & & $\mathrm{Ca}^{2+}$ & $\mathrm{SO}^{2-}$ & $\mathrm{Cl}^{-}$ & $\mathrm{CO}_{3}^{2-}$ \\
\hline 38 & 6 & & 6 & 5 & 40 & 5 \\
\hline
\end{tabular}




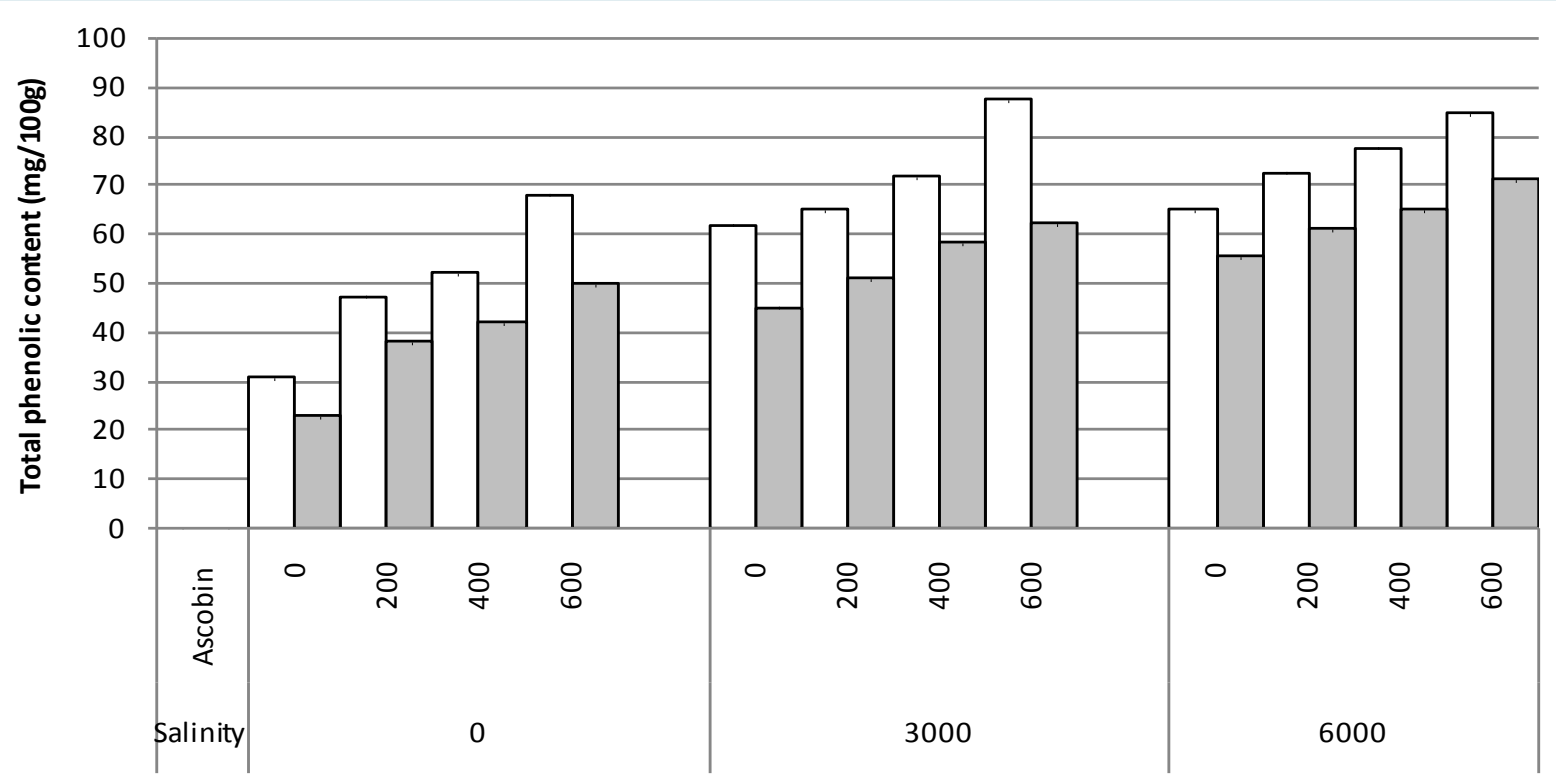

Figure 1. Effect of ascobin foliar treatment (mg/l) on and total phenolic contents (mg/100g) of two cultivars (Sids 1 and Giza 168) grown under salinity stress (mg/l) at 75 days from sowing. (White bars are of Sids 1 cultivar, grey bars are of Giza 168 cultivar $)$. LSD at 0.05 (Salinity $\times$ Ascobin $)=2.565$.

ascobin with different concentrations increased total phenolic contents as compared with control plant and the corresponding salinity levels. The potential of phenolics to act as an antioxidant is mainly due to their properties to act as hydrogen donators, reducing agents and quenchers of singlet $\mathrm{O}_{2}$ [25]. The synthesis of phenolics is generally affected in response to different biotic/abiotic stresses including salinity [26]. Higher activity of phenolics could be due to the greater $\mathrm{H}$-donating ability and radical stabilization than a variety of other antioxidant metabolites [25]. Levels of phenolic also increases under increasing levels of salinity, which shows that, the induction of secondary metabolism is one of the defense mechanisms adapted by the plants to face saline environment [27]. Also ascobin foliar treatment increased total phenol contents as compared with control plants and the corresponding salinity levels.

Lipid peroxidation: Variations in the contents of MDA are presented in Figure 2. Salinization significantly exerted increases in lipid peroxidation having a maximum at $6000 \mathrm{mg} / \mathrm{l}$ salinity level in the two tested wheat cultivars especially cultivar Sids 1. Foliar application of ascobin with different concentrations on wheat cultivars attenuated the effect of salinity compared with the corresponding salinity levels. [28] [29] reported that lipid peroxidation increased with salt levels on different plant species. These increases may be attributed to that salinity could modify the membrane structure and stimulate $\mathrm{O}_{2}$ production, which facilitates lipid peroxidation [30]. The inhibitory effects of exogenous ascorbic acid and citric acid on MDA were obtained on bean plants [31] and on bean plant [29]. The inhibitory effect of ascorbic acid on lipid peroxidation may be due to that antioxidant would inhibit stress-induced increases in the leakage of essential electrolytes following peroxidative damage to plasma membranes [31].

Antioxidant enzymes: With regard to antioxidant enzymes, the activity of antioxidant enzymes such as superoxide dismutase (SOD), catalase (CAT), peroxidase (POD), polyphenol oxidase (PPO), ascorbate peroxidase (AXP) and glutathione reductase (GR), activities dramatically increased due to salinity stress. The lowest and highest activity was observed in control and $6000 \mathrm{mg} / \mathrm{l}$ salinity stress treatments, respectively (Figure 3 and Figure 4). SOD and catalase increased significantly as salinity levels increased. In the current study, POD and PPO activities were enhanced as result of salinity stress (Figure 3 and Figure 4). The differences in the activity of antioxidant system among the two wheat cultivars revealed that salinity stress induce more activities of SOD and catalase enzymes in cultivar Sids 1 than in Giza 168 meanwhile the reverse were true in POD and PPO enzymes (activities higher in cultivar Giza 168 than in Sids 1) as compared with control plants. Thus, it could be concluded that there was a strong correlation between salt tolerance and enzyme activities. On the other hand, the activities of APX and GR were significantly increased in both cultivars under saline conditions. It is noticeable that the activities of APX and GR were greater in cultivar Sids 1 than Giza 168. 


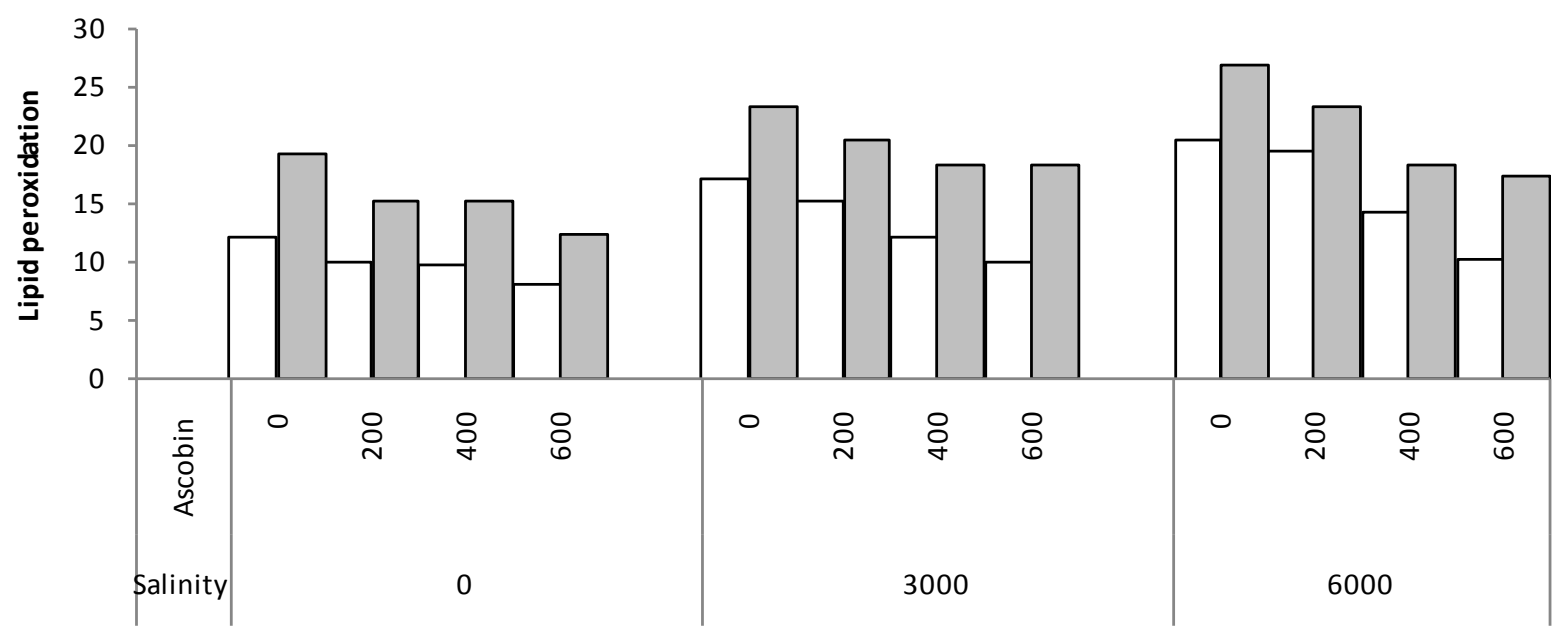

Figure 2. Effect of ascobin (mg/l) foliar treatment on lipid peroxidation ( $\mu \mathrm{mol} / \mathrm{g}$ fresh weight) of two cultivars (Sids 1 and Giza 168) grown under salinity stress at 75 days from sowing. (White bars are of Sids 1 cultivar, grey bars are of Giza 168 cultivar). LSD at 0.05 (Salinity $\times$ Ascobin $)=1.035$.

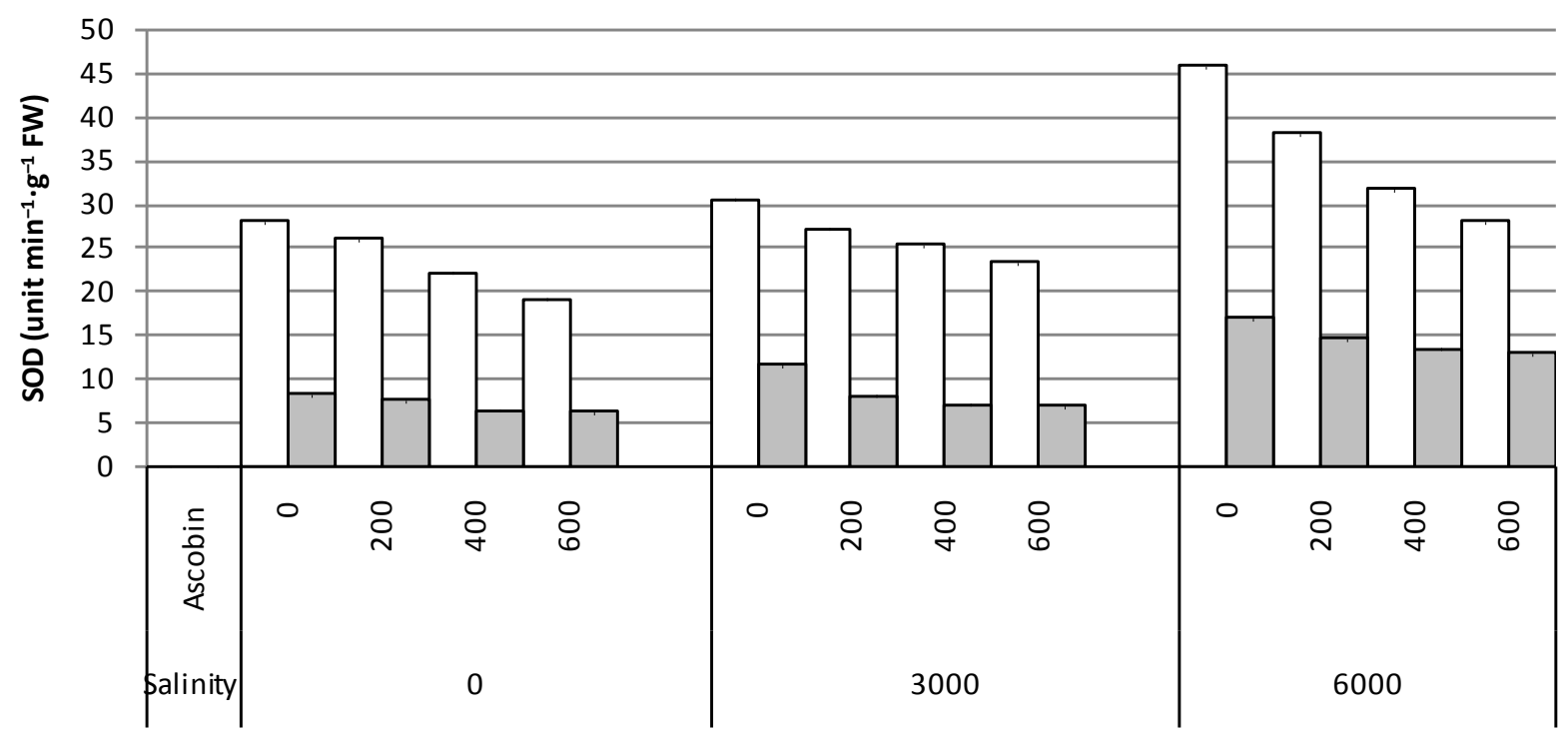

(a)

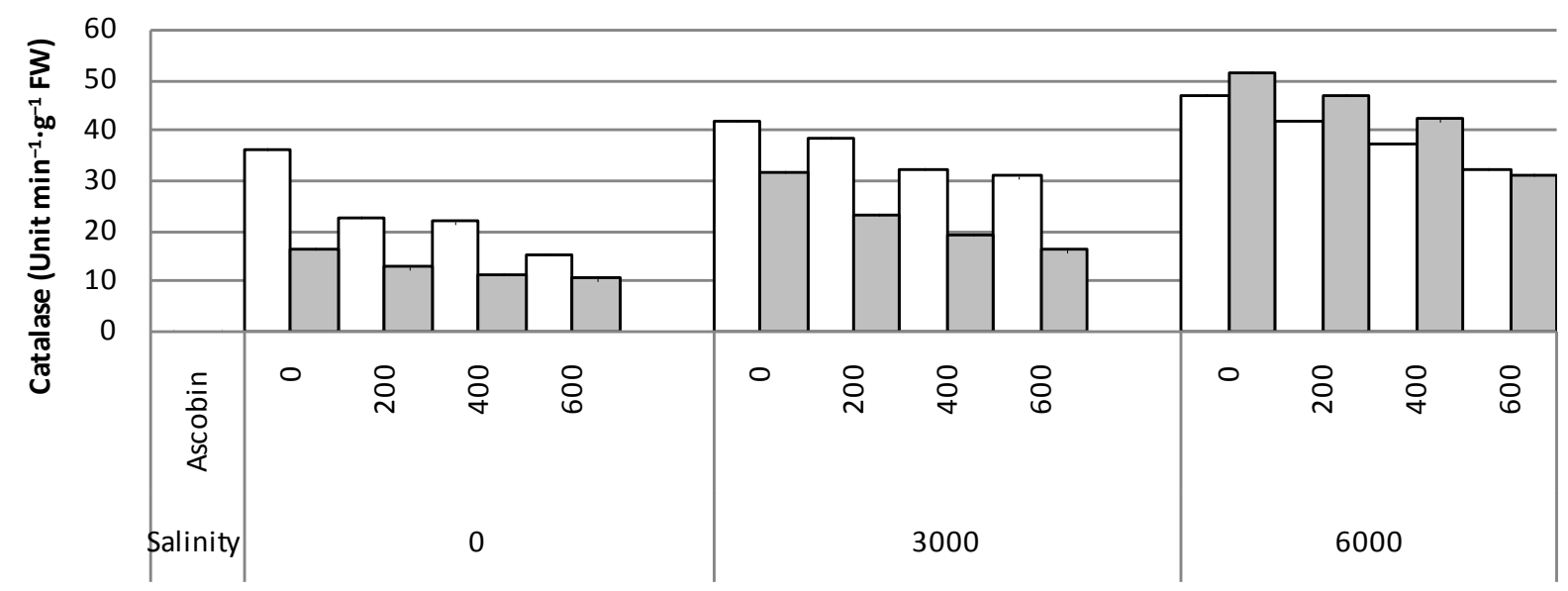

(b) 


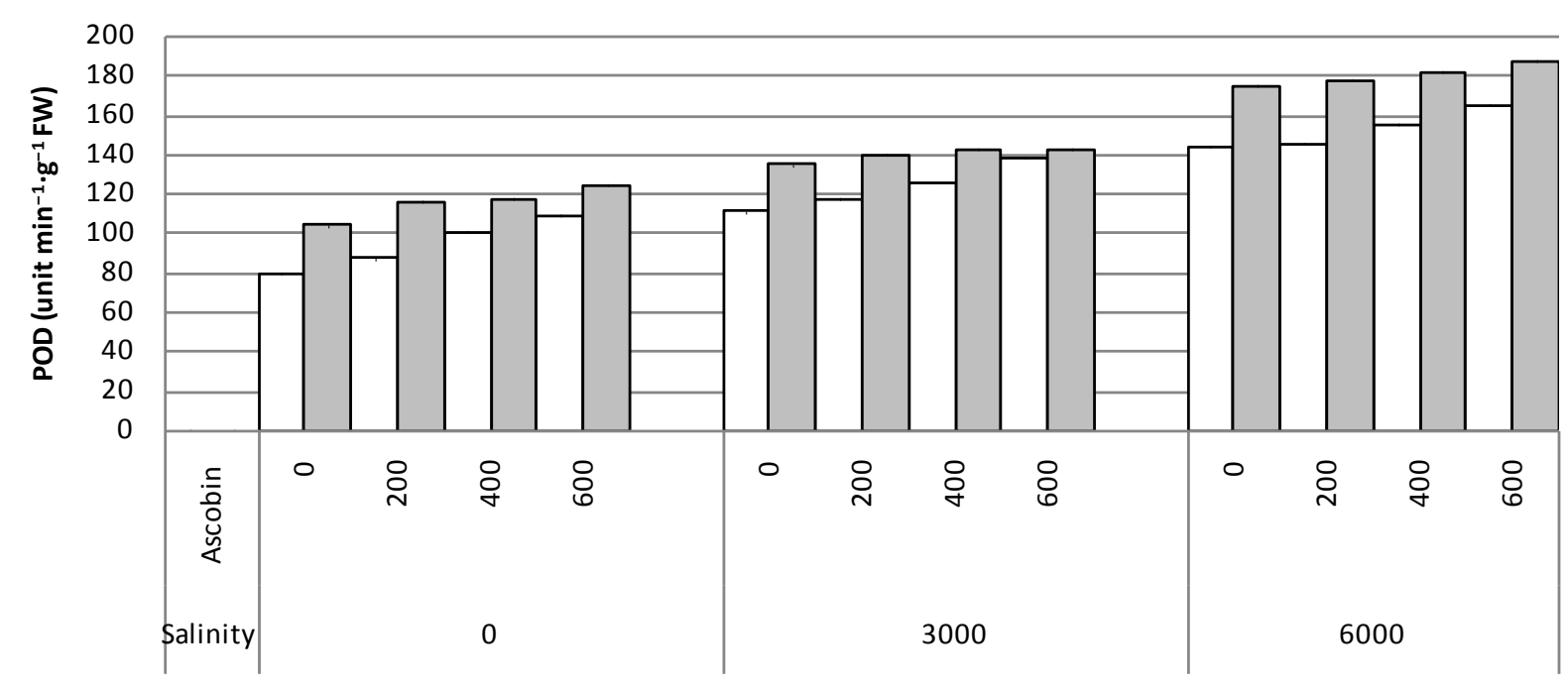

(c)

Figure 3. Effect of ascobin (mg/l) foliar treatment on antioxidant enzymes (a) superoxide dismutase (SOD), (b) catalase (CAT) and (c) peroxidase (POD), as unit $\mathrm{min}^{-1} \cdot \mathrm{g}^{-1} \mathrm{FW}$ of two cultivars (Sids 1 and Giza 168) grown under salinity stress at 75 days from sowing. (White bars are of Sids 1 cultivar, grey bars are of Giza 168 cultivar) LSD at 0.05 (Salinity $\times$ Ascobin) SOD: 2.37 , CAT: 4.366 and POD: 6.708.

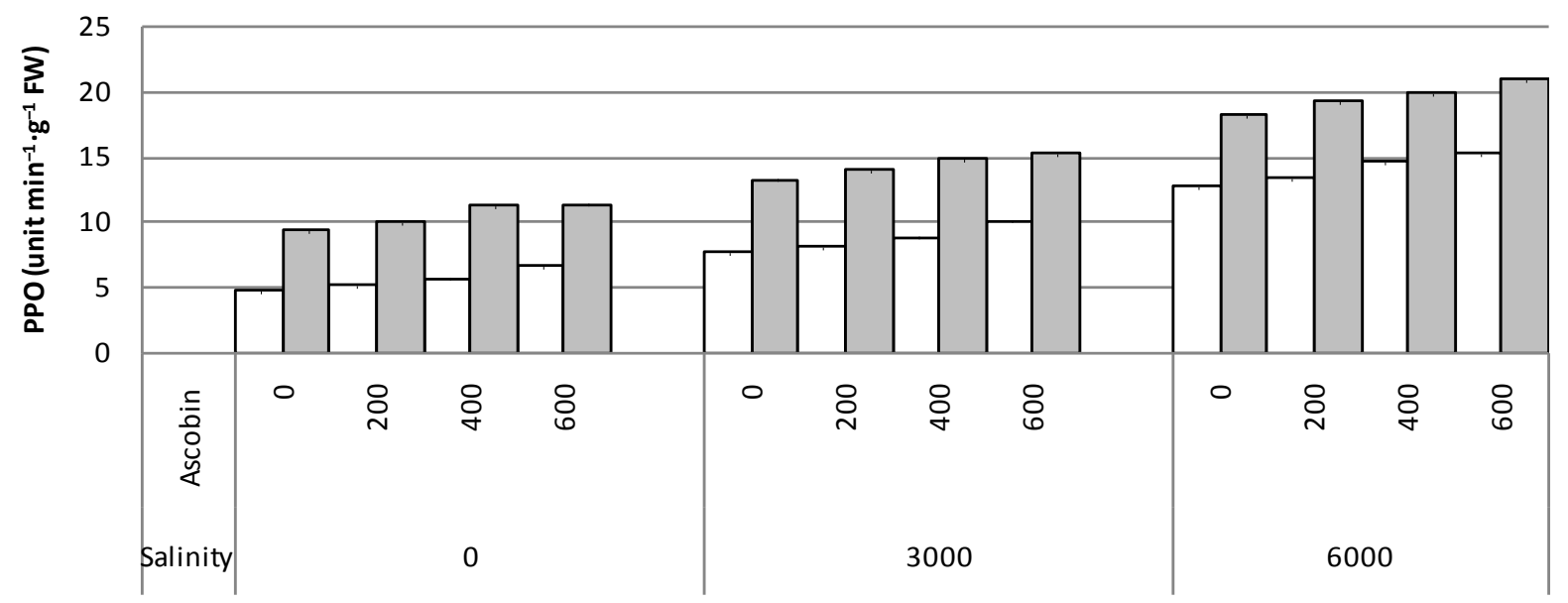

(a)

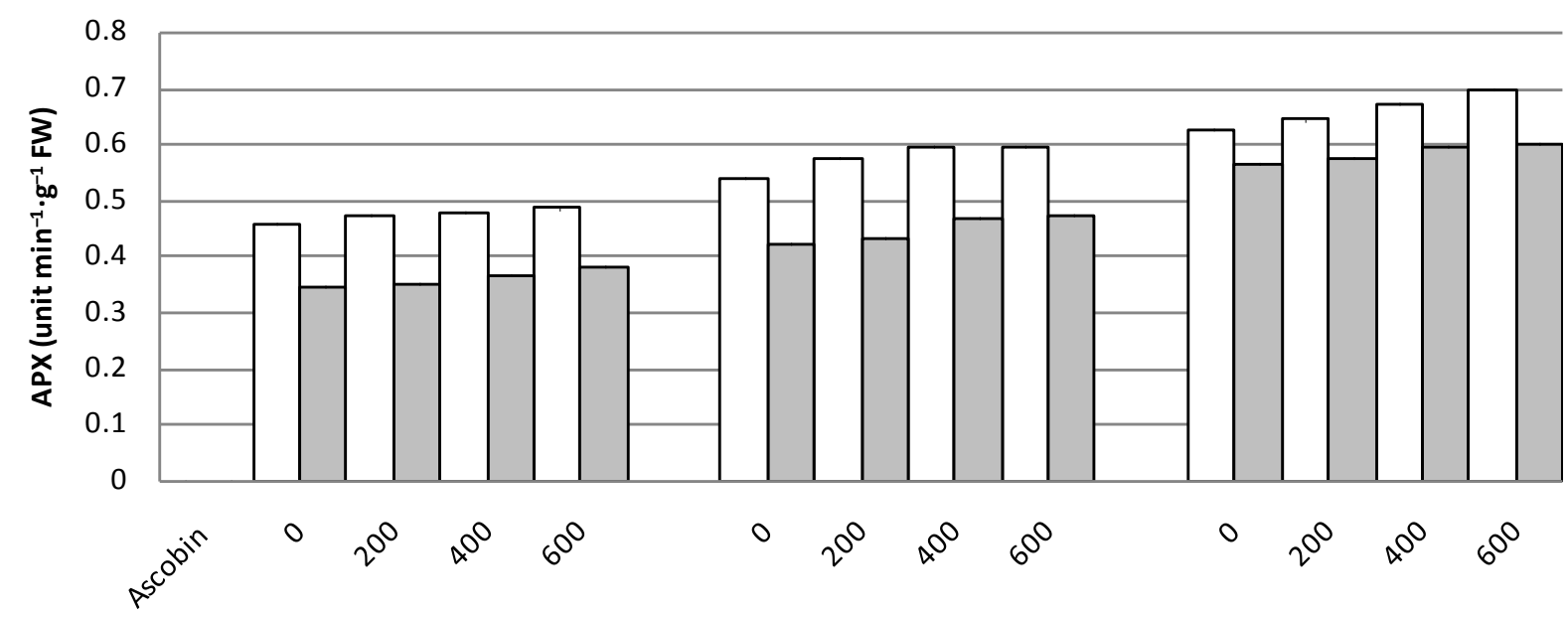

(b) 


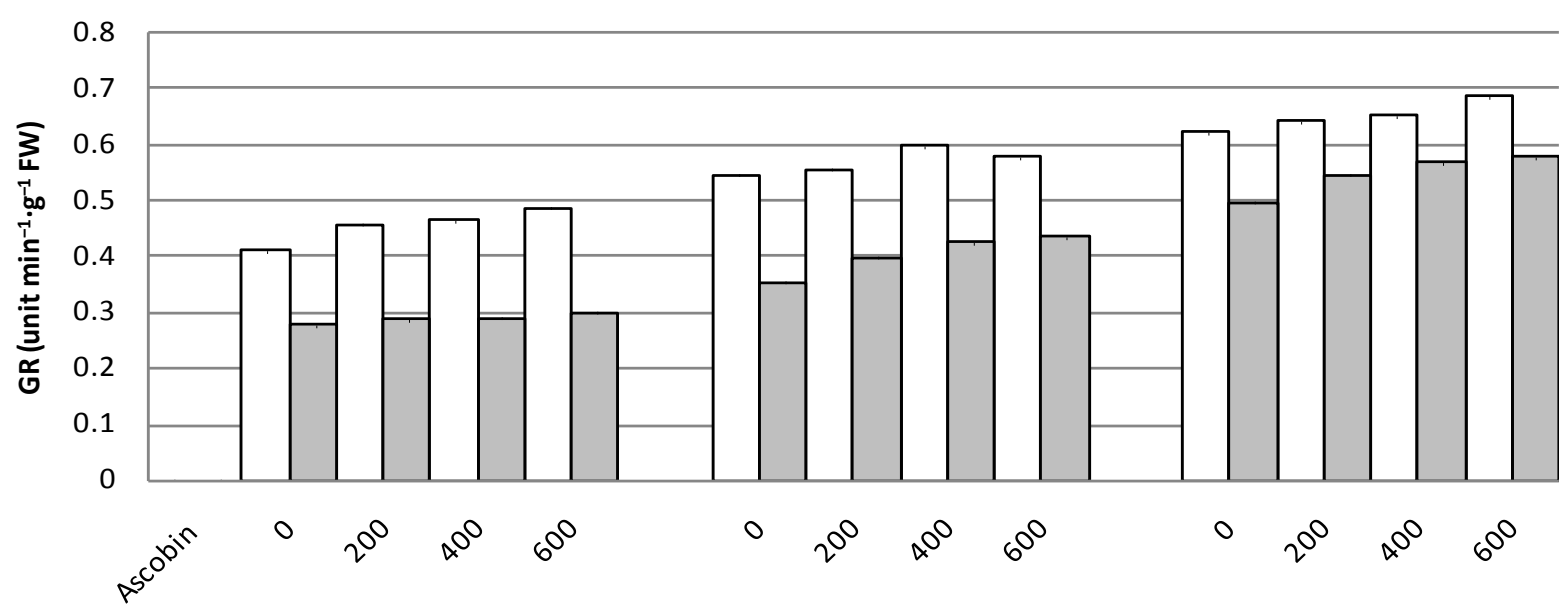

(c)

Figure 4. Effect of ascobin foliar treatment on antioxidant enzymes (a) polyphenol oxidase (PPO), (b) ascorbate peroxidase (APX) and (c) glutathione reductase (GR) as unit $\mathrm{min}^{-1} \cdot \mathrm{g}^{-1} \mathrm{FW}$ of two cultivars (Sids 1 and Giza 168) grown under salinity stress at 75 days from sowing. (White bars are of Sids 1 cultivar, grey bars are of Giza 168 cultivar) LSD at 0.05 (Salinity $\times$ Ascobin) PPO: 0.7752, APX: 0.0124 and GR: 0.032 .

With respect to ascobin treatment on the two cultivars, foliar treatment of ascobin with different concentrations markedly reduced the activity of SOD and catalase enzymes. In the meantime stimulated the activities of both POD and PPO enzymes in both wheat cultivars either under saline or non-saline conditions. Foliar treatment of ascobin markedly stimulated the activities of APX and GR enzymes in both wheat cultivars, either under saline or non-saline conditions (Figure 3 and Figure 4). The present obtained data of salinity are in agreement with those obtained by [32]-[34]. SOD is one of the ubiquitous enzymes in aerobic organisms essential for cellular defense mechanisms against ROS. SOD modulates relative amounts of $\mathrm{O}^{2-}$ and the two Haber-Wesis reaction substrates and decreases the risk of ${ }^{-} \mathrm{OH}$ radical formation, which is highly reactive and may cause severe damage to membranes and proteins [35]. The salt-induced enhancement of CAT activity in Sids 1 indicated that it had a higher capacity for the decomposition of $\mathrm{H}_{2} \mathrm{O}_{2}$ generated by SOD. Thus, CAT activity coordinated with SOD activity can represent a central protective role in the $\mathrm{O}^{2-}$ and $\mathrm{H}_{2} \mathrm{O}_{2}$ scavenging process, also CAT is the main scavenger of strong oxidant $\mathrm{H}_{2} \mathrm{O}_{2}$ in peroxisomes and it converts $\mathrm{H}_{2} \mathrm{O}_{2}$ to water and molecular oxygen [33]. Generally, the increases of CAT activity are a strategy for improving the salt tolerance [36]. The increased SOD and CAT activity in the leaves was more conspicuous in Sids 1. (salt-tolerant) than in Giza 168 (salt-sensitive), suggesting that salt-tolerant genotype has better $\mathrm{O}^{2-}$ radical scavenging ability. Meanwhile the reverse happen in POD and PPO activities in salt-sensitive cultivar are higher (Giza 168) than salt-tolerant cultivar (Sids 1), thereby enabling plants to protect themselves against oxidative stress (Figure 3). The active involvement of these enzymes is related, at least in part, to salt-induced oxidative stress tolerance in wheat plant. Like CAT, POD plays also a vital role in plant defense against oxidative stress by scavenging $\mathrm{H}_{2} \mathrm{O}_{2}$ in chloroplast, cytosol, mitochondria and peroxisome of plant cells [37].

Regarding to APX and GR, the higher activities of APX and GR in genotype Sids 1 than genotype Giza 168 were in agreement with those reported by [38], who concluded that under salinity stress, the stimulation of APX and GR activity was much higher in salt-tolerant than those of salt-sensitive cultivar. They also reported that the greater GR activity in salt stressed tolerant cultivar indicated that these plants exhibit more active ascorbateglutathione cycle than the non-tolerant cultivar. These results could interpret that salt tolerance of cultivar Sids 1 seems to be linked with increase in the activity of antioxidant enzymes. Foliar application of ascobin had a stimulating effect on some oxidative enzymes of both cultivars. These increases were concurrently with increasing protein levels indicating that vitamins could alleviate the inhibitory effects of salt stress by enhancing protein synthesis, as vitamins might act as activators for protein synthesis [39]. Also, it could be attributed to ascorbic acid and citric acid to have direct effects on scavenge ROS $\left(\mathrm{O}^{2-}\right)$, hydrogen peroxide $\left(\mathrm{H}_{2} \mathrm{O}_{2}\right)$ and singlet oxygen $\left(\mathrm{O}_{2}\right)$ [40]. From the present results, [41] reported that ascorbic acid plays an important role in preserving the activities of enzymes that contain prosthetic transition metal ions. Ascorbic acid acts as a primary substrate in cyclic pathway for enzyme detoxification of hydrogen peroxide [42]. In conclusion, it can be concluded that foliar 
spraying of ascobin can reduce the harmful effects of ROS and improves plant resistant under salt stress conditions.

Amino acid contents: With respect to amino acid contents of shoots of the two used cultivars of wheat, salinity stress with different concentrations caused marked increases in total amino acid contents, total essential amino acid contents (threonine, valine, methionine, leucine, isoleucine and phenylalanine) and increased the ratio of essential to non essential amino acids in Sids 1as compared to control plant. In the meantime, in cultivar Giza 168 it caused a slightly increases in the total amino acid contents, total essential amino acid contents, while decreased the ratio of essential to non essential amino acids. However, in the two cultivars especially at higher level $6000 \mathrm{mg} / \mathrm{l}$, the same treatments increased markedly glutamic, proline, tyrosine, histidine, lysine, $\mathrm{NH}_{4}^{+}$(is very toxic) and arginine contents compared with those of control plants (Table 2). In respect to ascobin foliar treatment, in most cases increases in the content of total amino acids, essential amino acids and the ratio of essential to non-essential amino acids were obtained compared to the corresponding salinity levels in the two genotypes Sids 1 and Giza 168 (Table 2). It is worthy to mention that, application of ascobin before exposing wheat plants to the different concentrations of salt resulted in an observed accumulation of glutamic, proline,

Table 2. The effect of ascobin foliar treatment on amino acid contents of shoot of two genotypes of wheat plant (Sids 1 and Giza 168) grown under salinity stress.

\begin{tabular}{|c|c|c|c|c|c|c|c|c|c|c|c|c|}
\hline Cultivar & \multicolumn{6}{|c|}{ Sids 1} & \multicolumn{6}{|c|}{ Giza 168} \\
\hline \multirow{2}{*}{$\begin{array}{l}\text { Salinity (mg/l) } \\
\text { Ascobin (mg/l) }\end{array}$} & \multicolumn{2}{|c|}{0} & \multicolumn{2}{|c|}{3000} & \multicolumn{2}{|c|}{6000} & \multicolumn{2}{|c|}{0} & \multicolumn{2}{|c|}{3000} & \multicolumn{2}{|c|}{6000} \\
\hline & 0 & 400 & 0 & 400 & 0 & 400 & 0 & 400 & 0 & 400 & 0 & 400 \\
\hline Aspartic acid & 7.13 & 10.36 & 15.31 & 11.66 & 9.21 & 10.36 & 6.36 & 9.36 & 4.63 & 6.90 & 3.11 & 9.36 \\
\hline Threonine ${ }^{*}$ & 3.91 & 5.35 & 7.76 & 4.47 & 7.13 & 3.36 & 3.11 & 6.07 & 2.90 & 3.98 & 2.11 & 2.80 \\
\hline Serine & 5.11 & 11.20 & 9.11 & 8.11 & 8.68 & 6.07 & 5.30 & 9.26 & 4.31 & 4.90 & 3.51 & 3.95 \\
\hline Glutamic & 17.61 & 35.71 & 25.00 & 49.07 & 27.55 & 60.57 & 43.57 & 63.99 & 60.61 & 68.30 & 69.46 & 83.50 \\
\hline Proline & 49.41 & 64.61 & 62.36 & 63.56 & 58.36 & 60.61 & 47.39 & 70.54 & 64.32 & 65.90 & 76.41 & 88.91 \\
\hline Glycine & 5.86 & 6.07 & 7.36 & 6.07 & 8.61 & 8.57 & 3.49 & 6.97 & 2.23 & 9.81 & 1.64 & 3.71 \\
\hline Cystine & 10.26 & 0.00 & 0.00 & 0.00 & 0.00 & 0.00 & 6.39 & 10.51 & 4.91 & 11.96 & 3.62 & 11.09 \\
\hline Alanine & 5.61 & 8.24 & 9.25 & 8.11 & 8.59 & 6.57 & 2.36 & 4.61 & 1.95 & 4.06 & 1.57 & 3.44 \\
\hline Valine $^{*}$ & 6.61 & 8.14 & 9.44 & 11.48 & 10.61 & 14.46 & 0.11 & 0.16 & 0.00 & 0.00 & 0.00 & 0.00 \\
\hline Methionine $^{*}$ & 0.41 & 0.86 & 0.36 & 0.82 & 0.21 & 0.62 & 0.44 & 0.00 & 0.18 & 0.11 & 0.11 & 0.09 \\
\hline Leucine $^{*}$ & 10.76 & 11.35 & 9.49 & 7.61 & 9.14 & 5.86 & 3.01 & 5.11 & 2.41 & 3.60 & 2.03 & 3.12 \\
\hline Isoleucine $^{*}$ & 12.61 & 18.11 & 9.24 & 14.21 & 14.92 & 15.86 & 1.81 & 4.64 & 1.36 & 3.72 & 3.54 & 3.24 \\
\hline Phenylalanine ${ }^{*}$ & 1.46 & 2.26 & 1.14 & 2.71 & 1.03 & 1.18 & 2.91 & 5.87 & 6.91 & 4.29 & 6.53 & 3.57 \\
\hline Tyrosine & 4.86 & 8.11 & 10.34 & 12.61 & 5.61 & 7.40 & 1.87 & 2.84 & 2.86 & 4.49 & 3.74 & 5.71 \\
\hline Histidine ${ }^{*}$ & 5.11 & 10.18 & 8.61 & 10.57 & 9.95 & 14.55 & 1.61 & 3.83 & 2.41 & 4.67 & 2.81 & 6.10 \\
\hline Lysine $^{*}$ & 10.68 & 16.21 & 11.13 & 18.11 & 12.61 & 18.11 & 1.38 & 3.38 & 1.58 & 5.57 & 1.68 & 6.10 \\
\hline $\mathrm{NH} 4$ & 15.61 & 8.23 & 17.61 & 10.07 & 20.36 & 10.71 & 10.86 & 5.61 & 16.09 & 12.25 & 22.57 & 10.20 \\
\hline Arginine ${ }^{*}$ & 9.11 & 18.41 & 10.36 & 20.07 & 11.07 & 19.08 & 1.73 & 3.13 & 1.91 & 3.48 & 2.03 & 3.62 \\
\hline Essential A A & 60.63 & 90.85 & 67.50 & 90.04 & 76.66 & 93.06 & 16.09 & 32.18 & 19.64 & 25.43 & 20.81 & 28.64 \\
\hline Non essential A A & 121.43 & 152.50 & 131.31 & 169.24 & 146.94 & 170.84 & 127.56 & 183.66 & 161.89 & 188.56 & 185.62 & 219.85 \\
\hline Total amino acids & 182.05 & 243.35 & 198.81 & 259.28 & 223.60 & 263.90 & 143.65 & 215.84 & 181.52 & 213.99 & 206.42 & 248.49 \\
\hline Ess AA/non Ess AA & 0.499 & 0.596 & 0.514 & 0.532 & 0.522 & 0.545 & 0.126 & 0.175 & 0.121 & 0.135 & 0.112 & 0.130 \\
\hline
\end{tabular}


tyrosine, histidine, lysine and arginine contents compared with those of control plants Table 2. Amino acids are directly or indirectly involved in the regulation of plant responses to environmental signals related to abiotic or biotic stress [43]. These obtained results are in agreement with the results obtained by the previous studies of [44] [45] on different plant species. The accumulation of total amino acids may be involved in osmotic adjustment, free radical scavenging and maintenance of protein and membrane integrity [46]. Among all individual free amino acids, proline (Pro) content in salt-treated leaves increased significantly in wheat cultivars. Proline serves as an important compatible osmolyte, and its accumulation is believed to reduce cellular water potential and avoid deleterious toxicity of high ionic strength, has also been proposed to serve as reactive oxygen species scavenger [47] and its accumulation can stabilize the structure of membranes and proteins to minimize the damage of cells under salt stress. In addition, a large increase in proline precursors, glutamate and arginine was observed in the two genotypes under salinity stress. A part from the considerable accumulation of proline and its precursors in wheat plant also induced an increases in isoleucine (Ile), leucine (Leu) and aspartate (Asp) contents. Amino acid accumulation (e.g. arginine and proline) may be considered as a detoxification mechanism of the ammonium produced in plants subjected to stress [48]. The interactive effect of different salinity levels and foliar spraying of ascobin on the two cultivars of wheat plant had increases in total amino acid and essential amino acids content. These increases in amino acids, especially proline can be one of these causes that the inhibitory effect of salinity was alleviated by ascobin foliar applications to wheat plant.

Inorganic solute composition: Table 3 illustrates the effect of ascobin on the ion composition of the two wheat cultivars grown under different levels of salinity. It is noticed that salinity treatment caused decreases in the contents of $\mathrm{N}, \mathrm{K}, \mathrm{Ca}, \mathrm{Mg}$, and P gradually as salinity increased. Salinity exerted a more pronounced effect on the nutrient content particularly for Giza 168 than for Sids 1. Na content increased gradually as salinity level increased, and consequently, the $\mathrm{K} / \mathrm{Na}$ ratio was decreased as compared with control ones. Foliar treatment with ascobin decreased the uptake of $\mathrm{Na}$, and increased the uptake of N, P, K, Ca and Mg in shoot of both wheat genotypes and furthermore, the K/Na ratios increased as compared with the control. Results also showed that 600 $\mathrm{mg} / \mathrm{l}$ of ascobin was more effective for increasing nutrient contents. These obtained results of salinity are in agreement with those obtained by [49] on wheat plant and [50] on flax plant. In this connection, [51] pointed out that salinization impaired $\mathrm{N}$ accumulation and incorporation into protein and raised total free amino acid accumulation in saline plant. Table 3, not only because of ionic strength effect that reduce the activity of phosphate

Table 3. Effect of ascobin foliar treatment on ion content (N, K, Ca, Mg, P and Na) (as mg/100g dry weight) of two genotypes (Sids 1 and Giza 168) grown under salinity stress.

\begin{tabular}{|c|c|c|c|c|c|c|c|c|c|c|c|c|c|c|c|}
\hline \multicolumn{2}{|c|}{ Treatment } & \multicolumn{2}{|c|}{ Nitrogen } & \multicolumn{2}{|c|}{ Potassium } & \multicolumn{2}{|c|}{ Calcium } & \multicolumn{2}{|c|}{ Magnesium } & \multicolumn{2}{|c|}{ Phosphorus } & \multicolumn{2}{|c|}{ Sodium } & \multicolumn{2}{|c|}{$\mathrm{K} / \mathrm{Na}$} \\
\hline $\begin{array}{c}\text { Salinity } \\
\mathrm{mg} / \mathrm{l}\end{array}$ & $\begin{array}{c}\text { Ascobin } \\
\mathrm{mg} / \mathrm{l}\end{array}$ & $\begin{array}{c}\text { Sids } \\
1\end{array}$ & $\begin{array}{c}\text { Giza } \\
168\end{array}$ & $\begin{array}{c}\text { Sids } \\
1\end{array}$ & $\begin{array}{c}\text { Giza } \\
168\end{array}$ & $\begin{array}{c}\text { Sids } \\
1\end{array}$ & $\begin{array}{c}\text { Giza } \\
168\end{array}$ & $\begin{array}{c}\text { Sids } \\
1\end{array}$ & $\begin{array}{c}\text { Giza } \\
168\end{array}$ & $\begin{array}{c}\text { Sids } \\
1\end{array}$ & $\begin{array}{c}\text { Giza } \\
168\end{array}$ & $\begin{array}{c}\text { Sids } \\
1\end{array}$ & $\begin{array}{c}\text { Giza } \\
168\end{array}$ & $\begin{array}{c}\text { Sids } \\
1\end{array}$ & $\begin{array}{c}\text { Giza } \\
168\end{array}$ \\
\hline \multirow{4}{*}{0} & 0 & 2912 & 2607 & 3663 & 2866 & 1176 & 1144 & 494 & 373 & 1889 & 1505 & 558 & 601 & 6.565 & 4.769 \\
\hline & 200 & 3199 & 2933 & 3912 & 3028 & 1285 & 1260 & 531 & 389 & 2295 & 1831 & 548 & 648 & 7.139 & 4.673 \\
\hline & 400 & 3400 & 3199 & 3980 & 3128 & 1402 & 1334 & 593 & 460 & 2493 & 2172 & 585 & 661 & 6.803 & 4.732 \\
\hline & 600 & 3667 & 3400 & 4131 & 3245 & 1433 & 1401 & 625 & 492 & 2558 & 2342 & 589 & 654 & 7.014 & 4.962 \\
\hline \multirow{4}{*}{3000} & 0 & 2550 & 2333 & 2671 & 2450 & 1114 & 1013 & 381 & 301 & 1533 & 1305 & 687 & 715 & 3.888 & 3.427 \\
\hline & 200 & 2824 & 2587 & 2961 & 2642 & 1254 & 1183 & 493 & 324 & 1768 & 1425 & 543 & 682 & 5.453 & 3.874 \\
\hline & 400 & 2968 & 2700 & 3132 & 2820 & 1378 & 1229 & 534 & 402 & 1879 & 1468 & 524 & 635 & 5.977 & 4.441 \\
\hline & 600 & 3120 & 3000 & 3425 & 2968 & 1419 & 1354 & 532 & 465 & 1918 & 1568 & 500 & 614 & 6.850 & 4.834 \\
\hline \multirow{4}{*}{6000} & 0 & 2290 & 2185 & 2401 & 2013 & 1084 & 958 & 328 & 296 & 1411 & 1187 & 635 & 745 & 3.781 & 2.702 \\
\hline & 200 & 2565 & 2367 & 2500 & 2132 & 1125 & 1060 & 401 & 325 & 1568 & 1302 & 601 & 714 & 4.160 & 2.986 \\
\hline & 400 & 2850 & 2500 & 2642 & 2358 & 1236 & 1142 & 443 & 356 & 1702 & 1402 & 568 & 668 & 4.651 & 3.530 \\
\hline & 600 & 2987 & 2800 & 2872 & 2543 & 1358 & 1258 & 481 & 378 & 1785 & 1514 & 658 & 654 & 4.365 & 3.888 \\
\hline \multicolumn{2}{|c|}{ LCD at $5 \%$} & \multicolumn{2}{|c|}{35.36} & \multicolumn{2}{|c|}{39.25} & \multicolumn{2}{|c|}{25.39} & \multicolumn{2}{|c|}{7.25} & \multicolumn{2}{|c|}{15.98} & \multicolumn{2}{|c|}{12.39} & \multicolumn{2}{|c|}{0.36} \\
\hline
\end{tabular}


but also because phosphate concentration in soil solution is tightly controlled by sorption processes and low solubility of Ca-P minerals. Therefore, it is understandable that phosphate concentration in field grown agronomic crops decreased as salinity increased [52]. Concerning potassium concentration, [53] found an increase in Na concentration and a decrease in $\mathrm{K}$ concentration in leaves with high salinity, due to a possible antagonism between $\mathrm{K}$ and $\mathrm{Na}$. This antagonism could be due to the direct competition between $\mathrm{K}$ and $\mathrm{Na}$ at the site of ion uptake at plasma lemma. The interactive effect of salinity and ascobin application act significantly on N, P, K, $\mathrm{Ca}, \mathrm{Mg}$ and Na uptake (Table 3). Under a good water irrigation and water salinity irrigation, the uptake of all nutrients increased when the rates of ascobin increased. This increasing up to the high rate of ascobin (600 ppm) increased N, P, K, Na, Ca and P uptake so ascobin played an important role of decreasing effects of salinity of water irrigation. [54] suggest that antioxidant as ascorbic acid and citric acid could be used as a potential growth regulator to improve plant salinity stress resistance. These increases in N, P, K, Mg and Ca may be attributed to the positive effect of ascobin on root growth which consequently increased the absorption of different nutrients and alleviating the harmful effects of salinity.

\section{Conclusion}

It could be concluded that the alternation in oxidative enzymes system, nutrient uptake and amino acids played an essential and decisive role in partially alleviating the adverse effect of salinity stress in wheat cultivars especially after application of ascobin at $600 \mathrm{mg} / \mathrm{l}$.

\section{References}

[1] Boyer, J.S. (1982) Plant Productivity and Environment. Science, 218, 443-448. http://dx.doi.org/10.1126/science.218.4571.443

[2] Gehlot, H.S., Purohit, A. and Shkhawat, N.S. (2005) Metabolic Changes and Protein Patterns Associated with Adaptation to Salinity in Sesamun Indicumcultivars. Journal of Cell and Molecular Biology, 4, 31-39.

[3] Jaleel, C.A., Kishorekumar, B., Manivannan, A., Sankar, B., Gomathinayagam, M. and Panneerselvam, R. (2008) Salt Stress Mitigation by Calcium Chloride in Phyllanthus amarus. Acta Botanica Croatica, 67, 53-62.

[4] Asada, K. (2000) The Water-Water Cycle as Alternative Photon and Electron Sinks. Philosophical Transactions of the Royal Society B, 355, 1419-1431. http://dx.doi.org/10.1098/rstb.2000.0703

[5] Azooz, M.M., Ismail, A.M. and Abou-Elhamed, M.F. (2009) Growth, Lipid Peroxidation and Antioxidant Enzyme Activities as a Selection Criterion for the Salt Tolerance of Three Maize Cultivars Grown under Salinity Stress. International Journal of Agriculture and Biology, 11, 21-26.

[6] Yildirim, B., Yaser, F., Ozpay, T., Ozpay, D.T., Turkozu, D., Terziodlu O. and Tamkoc, A. (2008) Variations in Response to Salt Stress among Field Pea Genotypes (Pisum sativum sp. arvense L.). Journal of Animal and Veterinary Advances, 7, 907-910.

[7] Zhang, S. and Klessing, D.F. (1997) Salicylic Acid Activities a 48-KOMAP Kinase in Tobacco. Plant Cell, 9, $409-424$. http://dx.doi.org/10.1105/tpc.9.5.809

[8] Givan, G.V. (1979) Metabolic Detoxification of Ammonia in Tissues of Higher Plants. Phytochemistry, 18, 375-382. http://dx.doi.org/10.1016/S0031-9422(00)81870-1

[9] Buettner G.R. and Schafer, F.Q. (2004) Ascorbate as an Antioxidant in Vitamin C. In: Asard, H., May, J.M. and Smirnoff, N., Eds., Functions and Biochemistry in Animals and Plants, Bios Scientific Publishers, Oxford, 173-188.

[10] Chen, Z. and Gallie, D.R. (2004) The Ascorbic acid Redox State Controls Guard Cell Signaling and Stomatal Movement. Plant Cell, 16, 1143-1162. http://dx.doi.org/10.1105/tpc.021584

[11] Wills, R., Lee, T., Graham, D., Mc-Glasson, W. and Hall, H. (1981) Postharvest: An Introduction to the Physiology and Handling of Fruit and Vegetables. CAB International, Wallingford.

[12] Stroganov, B.P. (1962) Physiological Basis of the Salt Tolerance of Plants (under Different Types of Soil Salinization). Izd-vo Akademii nauk SSSR, Moscow.

[13] Larsen, P. Harbo, A., Klungron, S. and Ashein, T.A. (1962) On the Biogenesis of Some Indole Compounds in Acetobacter xylinum. Physiologia Plantarum, 15, 552-565. http://dx.doi.org/10.1111/j.1399-3054.1962.tb08058.x

[14] Danil, A.D. and George, C.M. (1972) Peach Seed Dormancy in Relation to Endogenous Inhibitors and Applied Growth Substances. Journal of the American Society for Horticultural Science, 17, 621-624.

[15] Stewart, R.C. and Bewley, J.D. (1980) Lipid Peroxidation Associated with Accelerated Aging of Soybean Axes. Plant Physiology, 65, 245-248. http://dx.doi.org/10.1104/pp.65.2.245 
[16] Chapman, H.D. and Pratt, P.F. (1978) Methods of Analysis for Soils, Plant and Water. University of California Division of Agricultural Science, Berkeley.

[17] MuKherjee, S.P. and Choudhuri, M.A. (1983) Implication of Water Stress-Induced Changes in the Levels of Endogenous Ascorbic Acid and Hydrogen Peroxide in Vigna Seedling. Physiologia Plantarum, 58, 166-170. http://dx.doi.org/10.1111/j.1399-3054.1983.tb04162.x

[18] Dhindsa, R., Plumb-Dhindsa, P. and Thorpe, T. (1981) Leaf Senescence Correlated Permeability, Lipid Peroxidation and Decreased Levels of Superoxide Dismutase and Catalase. Journal of Experimental Botany, 32, 93-101. http://dx.doi.org/10.1093/jxb/32.1.93

[19] Chen, Y., Cao, X.D., Lu, Y. and Wang, X.R. (2000) Effect of Rare Earth Metal Ions and Their EDTA Complexes on Antioxidant Enzymes of Fish Liver. Bulletin of Environmental Contamination and Toxicology, 65, 357-365. http://dx.doi.org/10.1007/s001280000136

[20] Bergmeyer, H.U. (1974) Methods of Enzymatic Analysis I. 2nd Edition, Academic Press, New York.

[21] Kar, M. and Mishra, D. (1976) Catalase, Peroxidase and Polyphenol Oxidase Activities during Rice Leaf Senescence. Plant Physiology, 57, 315-319. http://dx.doi.org/10.1104/pp.57.2.315

[22] Chen, G. and Asada, K. (1992) Inactivation of Ascorbate Peroxidase by Thoils Requires Hydrogen Peroxide. Plant and Cell Physiology, 33, 117-123.

[23] Foyer, C.H. and Halliwell, B. (1976) The Presence of Glutathione and Glutathione Reductase in Chloroplasts: A Proposed Role in Ascorbic Acid Metabolism. Planta, 133, 21-25. http://dx.doi.org/10.1007/BF00386001

[24] MSTAT-C (1988) MSTAT-C, a Microcomputer Program for the Design, Arrangement, and Analysis of Agronomic Research. Michigan State University East Lansing, East Lansing.

[25] Rice-Evans, C., Miller, N.J. and Paganga, G. (1997) Antioxidant Properties of Phenolic Compounds. Trends in Plant Science, 2, 152-159. http://dx.doi.org/10.1016/S1360-1385(97)01018-2

[26] Parida, A. and Das, A.B. (2005) Salt Tolerance and Salinity Effects on Plants: A Review Original Research Article. Ecotoxicology and Environmental Safety, 60, 324-349. http://dx.doi.org/10.1016/j.ecoenv.2004.06.010

[27] Radi, A.A., Farghaly, F.A. and Hamada, A.M. (2013) Physiological and Biochemical Responses of Salt-Tolerant and Salt-Sensitive Wheat and Bean Cultivars to Salinity. Journal of Biology and Earth Sciences, 3, 72-88.

[28] El-Beltagi, H.S., Salama, Z.A. and El Hariri, D.M. (2008) Some Biochemical Markers for Evaluation of Flax Cultivars under Salt Stress Conditions. Journal of Natural Fibers, 5, 316-330. http://dx.doi.org/10.1080/15440470802252487

[29] Sadak, M.S., Abdelhamid, M.T. and El-Saady, M.A. (2010) Physiological Responses of Faba Bean Plant to Ascorbic Acid Grown under Salinity Stress. Egyptian Journal of Agronomy, 32, 89-106.

[30] Zhang, J. and Kirkham, M.B. (1996) Sorghum and Sunflower Seedlings as Affected by Ascorbic Acid, Benzoic Acid and Prophyl Gallate. Journal of Plant Physiology, 149, 489-493. http://dx.doi.org/10.1016/S0176-1617(96)80323-3

[31] Dolatabadian, A. and Jouneghani, R.S. (2009) Impact of Exogenous Ascorbic Acid on Antioxidant Activity and Some Physiological Traits of Common Bean Subjected to Salinity Stress. Notulae Botanicae Horti Agrobotanici Cluj-Napoca, 37, 165-172.

[32] Ebrahimian, E. and Bybordi, A. (2012) Effect of Salinity, Salicylic Acid, Silicium and Ascorbic Acid on Lipid Peroxidation, Antioxidant Enzyme Activity and Fatty Acid Content of Sunflower. African Journal of Agricultural Research, 7, 3685-3694.

[33] Bahari, A., Pirdashti, H. and Yaghubi, M. (2013) The Effects of Amino Acid Fertilizers Spraying on Photosynthetic Pigments and Antioxidant Enzymes of Wheat (Triticum aestivum L.) under Salinity Stress. International Journal of Agronomy and Plant Production, 4, 787-793.

[34] Zhang, L., Zhang, G., Wang, Y., Zhou, Z., Meng, Y. and Chen, B. (2013) Effect of Soil Salinity on Physiological Characteristics of Functional Leaves of Cotton Plants. Journal of Plant Research, 126, 293-304. http://dx.doi.org/10.1007/s10265-012-0533-3

[35] Bowler, C., Montagu, M.V. and Inze, D. (1992) Superoxide Dismutase and Salt Stress Tolerance. Annual Review of Plant Biology, 43, 83-116. http://dx.doi.org/10.1146/annurev.pp.43.060192.000503

[36] Vaidyanathan, H., Sivakumar, P., Chakrabarsty, R. and Thomas, G. (2003) Scavenging of Reactive Oxygen Species in NaCl-Stressed Rice (Oryza sativa L.) Differential Response in Salt-Tolerant and Sensitive Varieties. Plant Science, 165, 1411-1418. http://dx.doi.org/10.1016/j.plantsci.2003.08.005

[37] Asada, K. (2006) Production and Scavenging of Reactive Oxygen Species in Chloroplasts and Their Functions. Plant Physiology, 141, 391-396. http://dx.doi.org/10.1104/pp.106.082040

[38] Mandhania, S., Madan, S. and Sawhney, V. (2006) Antioxidant Defense Mechanism under Salt Stress in Wheat Seedlings. Plant Biology, 50, 227-231. http://dx.doi.org/10.1007/s10535-006-0011-7 
[39] Kodandaramaiah, J. (1983) Physiological Studies on the Influence of B-Vitamins on Leaf and Fruit Metabolism in Cluster Beans Cyamopsis tetagonoloba L. Tanb. Ph.D. Thesis, Sri Venkateswara University, Tirupati.

[40] Asada, K. (1999) The Water-Water Cycle in Chloroplasts: Scavenging of Active Oxygens and Dissipation of Excess photons. Annual Review of Plant Physiology and Plant Molecular Biology, 50, 601-639. http://dx.doi.org/10.1146/annurev.arplant.50.1.601

[41] Padh, H. (1990) Cellular Function of Ascorbic Acid. Biochemistry and Cell Biology, 68, 1166-1173. http://dx.doi.org/10.1139/o90-173

[42] Shalata, A. and Neumann, P.M. (2001) Exogenous Ascorbic Acid (Vitamin C) Increases Resistance to Stress and Reduces Lipid Peroxidation. Journal of Experimental Botany, 52, 2207-2221.

[43] Ashraf, M. and Harris, P.J.C. (2004) Potential Biochemical Indicators of Salinity Tolerance in Plants. Plant Science, 166, 3-16. http://dx.doi.org/10.1016/j.plantsci.2003.10.024

[44] Tammam, A.A., Alhamd, M.F.A. and Hemeda, M.M. (2008) Study of Salt Tolerance in Wheat (Triticum aestium L.) Cultivar Banysoif 1. Australian Journal of Crop Science, 1, 115-125.

[45] Kovács, Z., Simon-Sarkadi, L., Vashegyi, I. and Kocsy, G. (2012) Different Accumulation of Free Amino Acids during Short- and Long-Term Osmotic Stress in Wheat. The Scientific World Journal, 2012, Article ID: 216521.

[46] Keutgen, A.J. and Pawelzik, E. (2008) Contribution of Amino Acids to Strawberry Fruit Quality and Their Relevance as Stress Indicators under $\mathrm{NaCl}$ Salinity. Food Chemistry, 111, 642-647.

[47] Verbruggen, N. and Hermans, C. (2008) Proline Accumulation in Plants: A Review. Amino Acids, 35, 753-759. http://dx.doi.org/10.1007/s00726-008-0061-6

[48] Slocum, R.D. and Weinstein, K.H. (1990) Stress-Induced Putrescine Accumulation as a Mechanism of Ammonia Detoxification in Cereal Leaves. In: Flores, H.E., Ed., Polyamines and Ethylene: Biochemistry, Physiology and Interaction, American Society of Plant Biologists, Rockville, 157-167.

[49] Hozayn, M., Abd El-Monem, A.A., Abd El-hamidEbtihal, E.M. and Abdul Qados, A.M.S. (2013) Amelioration of Salinity Stress in Mungbean (Vigna radiate L). Plant by Soaking in Arginine. Journal of Applied Sciences Research, 9, 393-401.

[50] Sadak, M.S. and Dawood, M.G. (2014) Role of Ascorbic Acid and $\alpha$ Tocopherol in Alleviating Salinity Stress on Flax Plant (Linum usitatissimum L.). Journal of Stress Physiology \& Biochemistry, 10, 93-111.

[51] Hanafy, A.H. (1996) Physiological Studies on Tiploun and Nitrate Accumulation in Lettuce Plants. Mansoura University Journal of Agricultural Sciences, 21, 3971-3994.

[52] Mohamedin, A.A.M., Abd El-Kader, A.A. and Nadia, M.B. (2006) Response of Sunflower (Helianthus annuus L.) to Plants Salt Stress under Different Water Table Depths. Journal of Applied Sciences Research, 2, 1175-1184.

[53] Gemea, I., Navarro, J., Moral, R., Iborra, M., Palacios, G. and Mataix, J. (1996) Salinity and Nitrogen Fertilization Affecting the Macronutrient Content and Yield of Sweet Pepper Plants. Journal of Plant Nutrition, 19, 353-359. http://dx.doi.org/10.1080/01904169609365126

[54] Sheteaw, S.A. (2007) Improving Growth and Yield of Salt-Stressed Soybean by Exogenous Application of Jasmonic Acid and Ascobin. International Journal of Agriculture and Biology, 9, 473-478. 
Scientific Research Publishing (SCIRP) is one of the largest Open Access journal publishers. It is currently publishing more than 200 open access, online, peer-reviewed journals covering a wide range of academic disciplines. SCIRP serves the worldwide academic communities and contributes to the progress and application of science with its publication.

Other selected journals from SCIRP are listed as below. Submit your manuscript to us via either submit@scirp.org or Online Submission Portal.
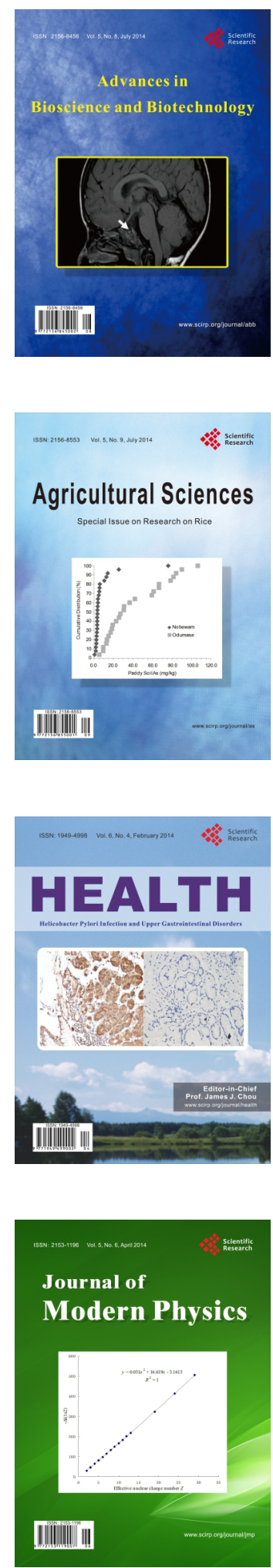
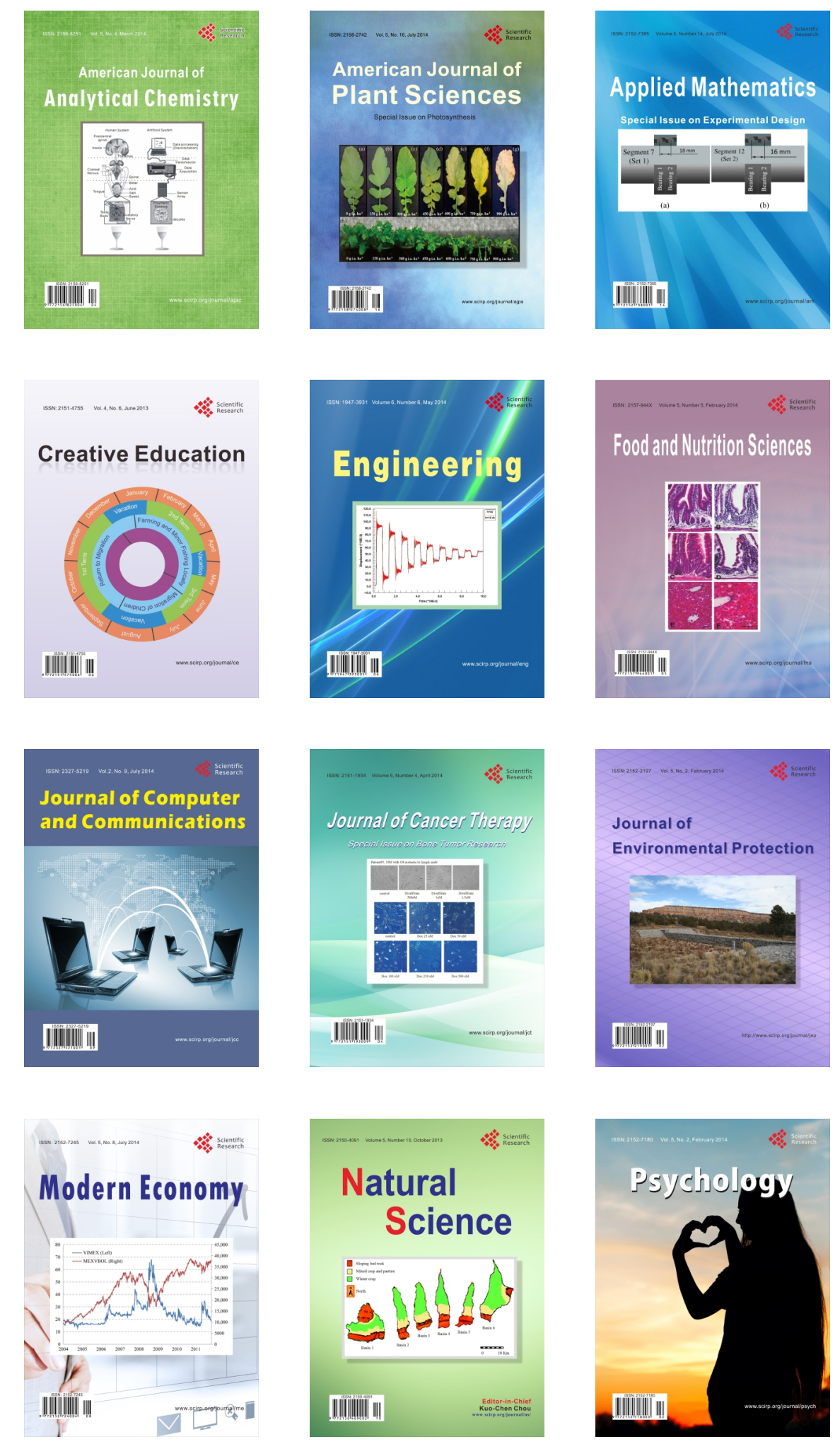